\title{
Extend Shelf-life of Vacuum-Packaged Herring Fish Fillets using Garlic and Ginger Extracts
}

\author{
El-Sohaimy Sobhy Ahmed ${ }^{1 *}$ (D), Mohamed G. Shehata ${ }^{1}$ (D) Hagar S. Abd-Rabou ${ }^{1}$ \\ and Hany El-Menshawy ${ }^{2}$
}

${ }^{1}$ Food Technology Department, Arid Lands Cultivation Research Institute, City of Scientific Research and Technological Application, Alexandria, Egypt. ${ }^{2}$ SummerMoon for Food Industries, Alexandria, Egypt.

\begin{abstract}
The present study explored the preservation effect of the garlic and ginger extract (GGE) on herring fish fillets under refrigerated storage $\left(4^{\circ} \mathrm{C}\right)$ for 8 weeks. The antioxidant and antimicrobial activity of GGE was evaluated: GGE exhibited a reasonable antioxidant activity and antimicrobial potency against some foodborne pathogens such as Bacillus subtilis DB 100 host, Clostridium botulinum ATCC 3584, Escherichia coli BA 12296, Salmonella senftenberg ATCC 8400, and Staphylococcus aureus NCTC 10788. The effect of GGE on the quality and shelf life of herring fish fillet was screened. The study findings highlight the effects of GGE treatment: significant microbial growth inhibition, postponed lipid oxidation, decreased thiobarbituric acid reactive substances (TBARS) concentration and decreased protein oxidation. Additionally, GGE treatment preserved the pleasant appearance of the fish compared to that of the control after 8 weeks of storage. This study verified that GGE effectively maintained herring fish fillet quality and safety compared to the control treatment and the treatments with nisin or butylated hydroxyl-toluene (BHT).
\end{abstract}

Keywords: Antioxidant activity; Antimicrobial activity; Herring fish; Lipid oxidation; Natural preservation; Protein oxidation.

*Correspondence: selsohaimy@srtacity.sci.eg

(Received: 10 June 2019; accepted: 23 July 2019)

Citation: El-Sohaimy Sobhy Ahmed, Mohamed G. Shehata, Hagar S. Abd-Rabou and Hany El-Menshawy, Extend Shelf-life of Vacuum-Packaged Herring Fish Fillets using Garlic and Ginger Extracts, J Pure Appl Microbiol., 2019; 13(3): 1571-1581. https:// doi.org/10.22207/JPAM.13.3.30

C The Author(s) 2019. Open Access. This article is distributed under the terms of the Creative Commons Attribution 4.0 International License which permits unrestricted use, sharing, distribution, and reproduction in any medium, provided you give appropriate credit to the original author(s) and the source, provide a link to the Creative Commons license, and indicate if changes were made. 


\section{INTRODUCTION}

Herring is a popular, preferred seafood due to its high protein and polyunsaturated fatty acid contents. Cooling and freezing are common methods for storing herring because of its fast spoilage. The high $\mathrm{pH}$ and amino acid, water and trimethylamine oxide contents ${ }^{1}$ of fish provide suitable conditions for gram-positive or gramnegative bacterial growth, which is the main cause of fish spoilage and enzymatic degradation, resulting in protein and lipid oxidation ${ }^{2}$. Fish polyunsaturated fatty acids (PUFAs) are essential to the good sensory properties of fish, and their hydrolysis and oxidation produce volatile compounds that influence the distinct flavours of the product ${ }^{3}$. Primary free radicals, hydroperoxides, secondary aldehydes and other oxidation products interfere with the cellular components involved in producing colour. On the other hand, protein oxidation causes a reduction in the water holding capacity, which negatively impacts product texture ${ }^{4}$. Herring fish deterioration causes health and economic problems, so finding innovative natural preservatives that ensure fish product safety and quality has become a great need ${ }^{5,6}$. Food manufacturers currently using some common synthetic preservatives like "BHT, BHA and THBQ" to extent shelf-life of herring fish products. Increasing consumer interest in healthy foods containing natural ingredients has driven demand away from synthetic chemicals because of the many health concerns associated with synthetic compounds ${ }^{7}$. Nisin has been the most common natural preservative used in the food industry for many years and is well known to inhibit most harmful bacteria (e.g., Listeria monocytogenes), particularly Clostridium and Bacillus species $8,9,10$. Nowadays, more attention was paid for the efficacy of different kinds of natural extracts to improve the shelf life of foods ${ }^{11,12,13,14,15}$ due to their high content of phenolic compounds, which enhance the sensory characteristics, quality and safety of food products.

Smoking is a natural traditional preservation method for fish products and is based on phenols and formaldehyde as smoking compounds. This process usually consists of salting and cooled storage, resulting in shelf life prolongation ${ }^{16}$.
During the storage of herring, lipid oxidation affects the fish quality through deterioration of the flavour, odour, colour, nutritional value, and safety of foods 5,17 .

In addition to serving as spices, ginger and garlic act as bio-preservatives due to their high content of bioactive components, such as phenolic compounds ${ }^{18}$. Several studies have focused on the effect of smoking and freezing on the oxidation of fish lipids ${ }^{19,20}$, but neglected the effect of smoking and the addition of natural antioxidants on lipid and protein oxidation and the shelf-life of herring fish consumed in Egypt. Thus, the aim of this work was to investigate the effect of novel formulas of ginger and garlic extract on lipid and protein oxidation and the shelf life of herring consumed in Egypt.

\section{METHODS}

\section{Raw material and chemicals}

Herring fish were obtained from the Summer Moon Company, and garlic and ginger were purchased from a local market. 2-2-Azinobis3-ethylbenthiazoline-6-sulphonic acid (ABTS), 1,1-diphenyl-2-picrylhydrazyl (DPPH), BHT, DNPH,2-thiobarbituric acid (TBA) and guanidine hydrochloride were procured from Alfa Aesar (Johnson Matthey, Massachusetts, USA). All other chemicals and reagents required were obtained from Merck (Germany).

\section{Preparation of herbal extracts}

Ginger and garlic extracts were prepared according to the method described by Cao et al. ${ }^{21}$ . Briefly, $20 \mathrm{~g}$ of a dried sample was extracted by refluxing for $1 \mathrm{~h}$ with $200 \mathrm{ml}$ of distilled water, and the obtained extract was cooled and filtered over Whattman no. 1 paper. The filtrates were pooled, concentrated under vacuum at $40^{\circ} \mathrm{C}$ and then lyophilized to obtain a water extract. A portion of the extract was diluted with distilled water to different concentrations for analysis.

\section{Total phenolic content}

The total phenolic content was determined according to Singleton et al. ${ }^{22}$ using the FolinCiocalteu reagent (Merck, Darmstadt, Germany) and calculated as gallic acid (mg) equivalents per gram by referring to slope and intercept data of the least-squares fit of a calibration curve computed using gallic acid as a reference standard. 


\section{Total flavonoids}

The flavonoid content was determined according to the method of Kim et al $2003^{23}$ which is based on the Flavonoid-Al(III) complex and measurement of the absorbance at $510 \mathrm{~nm}$. The total flavonoid content was calculated from a calibration curve generated using catechin as a standard and expressed as catechin (mg) equivalents per $100 \mathrm{~g}$ of dried sample.

\section{Antioxidant capacity ABTS| radical-scavenging activity}

Spectrophotometric analysis of the ABTS| radical-scavenging activity was evaluated according to the method of Shirwaikar et al. (2006) ${ }^{24}$. This method is based on the ability of antioxidants to quench the long-lived ABTS radical cation, a blue/green chromophore with distinctive absorption at $734 \mathrm{~nm}$, in comparison to the quenching ability of standard antioxidants. The ABTS| activity was calculated by the following formula:

$$
\begin{gathered}
\text { ABTS'+activity (\% inhibition) }= \\
{\left[\left(A t_{0}-A t_{20}\right) / A t_{0}\right] \times 100} \\
\text { DPPH radical-scavenging activity }
\end{gathered}
$$

The ability of a ginger extract, a garlic extract and a mixture of the two to scavenge DPPH radicals was estimated following the method of Kato et al. (1988) ${ }^{25}$. DPPH can create stable free radicals in aqueous or ethanol solutions. The free radical-scavenging activity was evaluated as the decrease in absorbance due to the scavenging activity:

\section{(\%) Inhibition) $=100-\left(\mathrm{At}_{20} / \mathrm{At}_{0}\right) \times 100$ \\ Antimicrobial activity}

The agar well diffusion method was used to determine the diameters of inhibition zones made by plant extracts of garlic and ginger against various pathogenic strains (B. subtilis DB 100 host, C. botulinum ATCC 3584, E. coli BA 12296, S. senftenberg ATCC 8400, S. aureus NCTC 10788). Tests were performed in triplicate ${ }^{26}$.

\section{Storage experiments}

Ten kilograms of fresh filleted herring fish (Clupeaharengus) were obtained from the Summer Moon Company and divided up for the following treatments: $\mathrm{TO}=$ control without any additives; $\mathrm{T} 1=$ with nisin; $\mathrm{T} 2=$ with herbal extract; $\mathrm{T} 3=$ with $\mathrm{BHT}$; all tissue samples were vacuum packaged in oxygen-impermeable bags (PET+VMPET+LDPE, $120 \mu \mathrm{m}$ ) and stored at $4{ }^{\circ} \mathrm{C}$.
Sampling was carried out at time zero and after $2,4,6$ and 8 weeks of storage at $4^{\circ} \mathrm{C}$.

\section{Lipid oxidation in herring fish}

The oxidative stability of herring fish was estimated using 2-thiobarbituric acid reactive substances (TBARS) according to the guidelines of Liu et al. (2010) ${ }^{27}$. In this context, $5 \mathrm{~g}$ of fish samples were weighed in a $50 \mathrm{~mL}$ Falcon tube and homogenized with $50 \mathrm{LL}$ of BHT (7.2\%) and $15 \mathrm{~mL}$ of deionized distilled water using a homogenizer for $15 \mathrm{~s}$. One millilitre of fish homogenate was transferred to a disposable test tube $\left(13^{\prime} 100\right.$ $\mathrm{mm}$ ), and $2 \mathrm{~mL}$ of TBA/trichloroacetic acid (TCA; $15 \mathrm{mM}$ TBA/15\% TCA) solution was added. The mixture was vortexed and incubated in a boiling water bath for $15 \mathrm{~min}$ to develop the colour. Afterwards, samples were cooled in ice water for $10 \mathrm{~min}$, vortexed again and centrifuged for $15 \mathrm{~min}$ at $2000^{\prime} \mathrm{g}$ and $4^{\circ} \mathrm{C}$. The absorbance of the resulting supernatant was determined at $531 \mathrm{~nm}$ against a blank containing $1 \mathrm{~mL}$ of deionized distilled water and $2 \mathrm{~mL}$ of TBA/TCA solution. The content of TBARS was expressed as $\mathrm{mg}$ of malondialdehyde (MDA)/kg of fish.

\section{Protein oxidation in herring fish}

Protein oxidation was evaluated on the basis of both the formation rate of carbonyl groups and the loss rate of sulphydryl groups. The total carbonyl content was determined by the procedure of Oliver et al. $1987^{28}$. Briefly, 1 $\mathrm{g}$ of fish was homogenized with $20 \mathrm{ml}$ of $0.05 \mathrm{M}$ phosphate buffer (pH 7.2), and a $0.5 \mathrm{ml}$ aliquot of the homogenate was mixed with $0.5 \mathrm{ml}$ of $20 \%$ TCA and centrifuged. The precipitated proteins were washed twice with $\mathrm{HCl} /$ acetone $(3 / 100, \mathrm{v} / \mathrm{v})$, followed by washing with $10 \%$ TCA to remove fish chromophores. One of the precipitates was treated with $1 \mathrm{ml}$ of $2 \mathrm{~N} \mathrm{HCl}$ for protein quantification, and the other was treated with $1 \mathrm{ml}$ of DNPH $0.2 \%$ $(\mathrm{w} / \mathrm{v})$ in $2 \mathrm{~N} \mathrm{HCl}$ for carbonyl quantification. Both solutions were incubated in the dark for $1 \mathrm{~h}$ at room temperature under regular stirring, the contents were centrifuged, and the precipitates were washed once with $5 \mathrm{ml}$ of $20 \%$ TCA and three times with $5 \mathrm{ml}$ of ethanol/ethyl acetate $(1 / 1$, $\mathrm{v} / \mathrm{v}$ ) to eliminate traces of DNPH. The precipitates were finally dissolved in $2 \mathrm{ml}$ of $6 \mathrm{M}$ guanidine hydrochloride with $20 \mathrm{mM}$ sodium phosphate buffer, $\mathrm{pH}$ 6.5. The protein concentration was calculated from the absorption at $280 \mathrm{~nm}$ of 
the sample derived from the precipitate treated with $\mathrm{HCl}$. For quantification purposes, a standard solution of bovine serum albumin (BSA) in 20 $\mathrm{mM}$ sodium phosphate buffer with $6 \mathrm{M}, \mathrm{pH} 6.5$, guanidine hydrochloride was prepared, and the protein concentration was determined according to a standard curve. The carbonyl concentration was calculated from the absorption at $370 \mathrm{~nm}$ of the sample derived from the precipitate treated with DNPH and expressed as nmol of carbonyls/ $\mathrm{mg}$ of protein using an adsorption coefficient of $22.0 \mathrm{mM}^{\prime \prime} \mathrm{cm}^{\prime \prime}$.

\section{Microbiological analysis}

Fish samples (10 g) were weighed aseptically in sterile bottles, and 10 volumes of sterile saline solution $(8.5 \mathrm{~g} / \mathrm{L})$ were added. After homogenization for $1 \mathrm{~min}$, a series of 10 -fold dilutions were prepared using saline. Nutrient agar was used for total aerobes, while violet red bile agar medium was used for Enterobacteriaceae bacteria ${ }^{29}$. Salmonella-Shigella (SS) agar and mannitol salt agar were used for Salmonella sp. and S. aureus ${ }^{30,31}$, respectively. Plates for the enumeration of Staphylococci sp., coliforms, total aerobes and Salmonella sp. were incubated at $37^{\circ} \mathrm{C}$ for $48 \mathrm{~h}$. The results are expressed as $\log _{10} \mathrm{CFU}$ per g.

\section{Electrophoresis}

The polypeptide pattern of brines was analysed using sodiumdodecyl sulphatepolyacrylamide gel electrophoresis (SDS-PAGE). Fish samples were diluted to $1 \mathrm{mg} / \mathrm{mL}$ with $50 \mathrm{mM}$ Tris buffer ( $\mathrm{pH}$ 7.4) containing 1 mM EDTA (Merck, Darmstadt, Germany) and further mixed 1:1 (v:v) with Laemmli buffer containing10\% DDT (SigmaAldrich, Steinheim, Germany). Subsequently, the mixture was boiled for $3 \mathrm{~min}$ and centrifuged for 3 $\mathrm{min}$ at $6000 \mathrm{~g}$. Samples and a See-Blue Standard (10 $\mathrm{xL}$ ) were loaded onto a $12 \%$ SDS-PAGE gel and run with running buffer at $200 \mathrm{~V}$ for approximately 50 min. Finally, the gels were stained with Coomassie Brilliant Blue G-250 overnight and washed with a distaining solution ( $15 \%$ ethanol and $5 \%$ acetic acid) until protein bands became clearly visible in the colourless gel matrix.

\section{Sensory evaluation of herring fish}

The attributes of herring fish (colour, odour, taste, texture, appearance and overall acceptance) were evaluated by a well-trained 10-members panel of laboratory of Food
Technology. Sensory evaluation was based on a nine-point scale according to Lawless et al. ${ }^{32}$ : "Dislike extremely" was represented by a score of 1,5 represented "neither like nor dislike" and 9 represented "like extremely".

\section{Statistical analysis}

Significant differences between results were calculated by one-way analysis of variance (ANOVA) and Duncan's test. Differences were considered significant at $P<0.05$ (95\% confidence level). All statistical analyses were performed with SPSS 16.

\section{RESULTS AND DISCUSSION \\ Impact of the herbal extract on antioxidant activity}

The antioxidant activity of the ginger and garlic extracts and their mixture was measured using two parallel assays: DPPH and ABTS. The extracts exhibited significant $(P<0.05)$ scavenging activities at high concentrations $(25-100 \mathrm{mg})$. Ginger extract showed a significantly $(P<0.05)$ higher scavenging activity than garlic extract and the mixture of garlic and ginger. The $\mathrm{IC}_{50}$ was $20.43 \mu \mathrm{g} / \mathrm{ml}$ for ginger, $42.13 \mu \mathrm{g} / \mathrm{ml}$ for garlic and $18.10 \mu \mathrm{g} / \mathrm{ml}$ for the mixture on the basis of the DPPH assay and $30.76 \mu \mathrm{g} / \mathrm{ml}$ for ginger, $45.51 \mu \mathrm{g} /$ $\mathrm{ml}$ for garlic and $28.96 \mu \mathrm{g} / \mathrm{ml}$ for the mixture on the basis of the ABTS assay (Table (1)).Polyphenol compounds such as flavonoids, flavonols, proanthocyanidin and phenolics in plants have been reported to have strong antioxidant activities, which help to protect cells against oxidative damage by free radicals (McCune and John, 2002; Liao et al., 2008).The model of scavenging the stable DPPH radical is a widely used method for evaluating the free radical-scavenging ability of various compounds ${ }^{33}$. Table (1) depicts that the DPPH-scavenging activities of all the extracts and standards are dose responsive; that is, the higher the concentration is, the greater the scavenging activity. The high antioxidant activity of $A$. sativum has been reported by Benkeblia et al. (2005) ${ }^{34}$, but the activity of alliums depends on both phenolics and sulphur compounds. Nuutila et al. (2003) ${ }^{35}$, in a study comparing the antioxidant properties of different allium species, and ${ }^{36}$ Capasso $(2013)^{36}$, in a study evaluating the antioxidant action of garlic, reported that the lowest antioxidant activity was in garlic (A. sativum), which is similar to the trend 
observed in this study between the activities of garlic, ginger and the mixture of the two spices, as garlic showed the lowest DPPH- and ABTS radicalscavenging activity. According to Ghasemzadeh et al. (2010) ${ }^{37}$, ginger showed high antioxidant activity with DPPH, which is similar to our observation in the present study, as ginger showed high DPPH- and ABTS-scavenging activities. We report here for the first time that the antioxidant activity was significantly increased in the mixture of garlic and ginger without any correlation with the phenolic content. This increase could be due to the synergism of the antioxidant activities of the two species.

\section{Antimicrobial activity of the herbal extracts}

Aqueous extracts of ginger, garlic and their mixture were screened for antimicrobial activity against five bacterial species $(B$. subtilis DB 100 host, C. botulinum ATCC 3584, E. coli BA 12296, S. senftenberg ATCC 8400 and S. aureus NCTC 10788) using the well diffusion method. The mixture of ginger and garlic extracts showed the highest antimicrobial activity, and its sensitivity differed among the tested strains. The results shown in Table (2) display high antimicrobial activity of the extracts, but the sensitivity differed among the tested strains. Ginger and garlic extract mixtures exhibited stronger antimicrobial effects than the individual extracts. S. senftenberg ATCC 8400 exhibitedthe largest inhibition zone of $29 \pm$ $1.05 \mathrm{~mm}$ against the extract mixture, followed by B. subtilis DB 100 hostat $28.8 \pm 1.05 \mathrm{~mm}$, while $C$. botulinum ATCC 3584 showed the lowest inhibition zone of $21 \pm 1.05 \mathrm{~mm}$. GGE has antibacterial effects on both gram-positive and gram-negative bacteria, although the antimicrobial mechanism of action is different for each type. This may be attributed to the high phenolic compound content of the extract, which is common in most plant extracts and serves as a defence mechanism against biological attack ${ }^{38,39,14}$.

\section{Microbiological analysis of herring}

Microorganism growth, both pathogenic and non-pathogenic, causes unfavourable changes in food products, making it unsuitable or unsafe

Table 1. Scavenging effects of aqueous extracts of ginger and garlic and their mixture on DPPH and ABTS radicals

\begin{tabular}{lcccccc}
\hline $\begin{array}{l}\text { Concentration } \\
\text { of samples } \\
(\mu \mathrm{g} / \mathrm{ml})\end{array}$ & Ginger & $\begin{array}{c}\text { \% Inhibition of DPPH } \\
\text { Garlic }\end{array}$ & Mix* & Ginger & $\begin{array}{c}\text { \% Inhibition of ABTS } \\
\text { Garlic }\end{array}$ & Mix* $^{*}$ \\
\hline 25 & & & & & & \\
50 & $61.30 \pm 0.98^{\mathrm{a}}$ & $52.83 \pm 1.75^{\mathrm{b}}$ & $62.90 \pm 1.65^{\mathrm{a}}$ & $40.6 \pm 1.60^{\mathrm{a}}$ & $37.83 \pm 1.25^{\mathrm{b}}$ & $43 \pm 1.00^{\mathrm{a}}$ \\
75 & $68.46 \pm 0.89^{\mathrm{a}}$ & $59.30 \pm 0.79^{\mathrm{b}}$ & $74.23 \pm 0.30^{\mathrm{a}}$ & $51.56 \pm 1.72^{\mathrm{a}}$ & $46.50 \pm 1.41^{\mathrm{b}}$ & $54.33 \pm 1.40^{\mathrm{a}}$ \\
100 & $81.50 \pm 1.10^{\mathrm{a}}$ & $68.30 \pm 0.98^{\mathrm{b}}$ & $85.56 \pm 1.43^{\mathrm{a}}$ & $59.63 \pm 1.76^{\mathrm{a}}$ & $54.96 \pm 1.86^{\mathrm{b}}$ & $65.13 \pm 1.02^{\mathrm{a}}$ \\
$\mathrm{IC}_{50}(\mu \mathrm{g} / \mathrm{ml})$ & $20.43 \pm 0.15^{\mathrm{b}}$ & $42.13 \pm 0.53^{\mathrm{a}}$ & $18.10 \pm 1.51^{\mathrm{c}}$ & $30.76 \pm 1.19^{\mathrm{b}}$ & $45.51 \pm 1.54^{\mathrm{a}}$ & $28.96 \pm 0.85^{\mathrm{b}}$ \\
\hline
\end{tabular}

Values are the mean $\pm S D(n=3)$. Different lowercase letters within the same row indicate significant differences $(p<0.05)$. *Mix (1:10) 1Ginger: 10Garlic

Table 2. Antimicrobial activity of aqueous extracts of ginger and garlic and their mixture against pathogenic bacteria

\begin{tabular}{lccccc}
\hline Samples & $\begin{array}{c}\text { Bacillus } \\
\text { subtilis DB } \\
100 \text { host }\end{array}$ & $\begin{array}{c}\text { Clostridium } \\
\text { botulinum } \\
\text { ATCC } 3584\end{array}$ & $\begin{array}{c}\text { Strains } \\
\text { Escherichia } \\
\text { coli BA } \\
12296\end{array}$ & $\begin{array}{c}\text { Salmonella } \\
\text { senftenberg } \\
\text { ATCC } 8400\end{array}$ & $\begin{array}{c}\text { Staphylococcus } \\
\text { aureus } \\
\text { NCTC } 10788\end{array}$ \\
\hline $\begin{array}{l}\text { Ginger } \\
\text { Garlic }\end{array}$ & $15.23 \pm 2.15^{\mathrm{c}}$ & $11.5 \pm 1.32^{\mathrm{c}}$ & $18.23 \pm 1.75^{\mathrm{c}}$ & $21.5 \pm 1.50^{\mathrm{c}}$ & $17.23 \pm 0.92^{\mathrm{c}}$ \\
Mixture* & $23.33 \pm 1.04^{\mathrm{b}}$ & $14.16 \pm 1.03^{\mathrm{b}}$ & $23.66 \pm 1.60^{\mathrm{b}}$ & $26.16 \pm 0.76^{\mathrm{b}}$ & $21.06 \pm 0.81^{\mathrm{b}}$ \\
$28.8 \pm 1.05^{\mathrm{a}}$ & $21 \pm 1.05^{\mathrm{a}}$ & $28.06 \pm 1.05^{\mathrm{a}}$ & $29 \pm 1.05^{\mathrm{a}}$ & $25.06 \pm 1.05^{\mathrm{a}}$
\end{tabular}

Values are the mean $\pm S D(n=3)$. Different lowercase letters within the same column indicate significant differences $(p<0.05)$. ${ }^{*}$ Mix (1:10)1Ginger: 10Garlic 
for consumption. Antioxidant compounds from different natural sources have proven to be effective antimicrobial agents $40,41,13,14$. Extracts of ginger and garlic and their mixture have strong antimicrobial activity against some pathogenic bacteria ${ }^{42,43}$. However, the antimicrobial effects of ginger, garlic and their mixture have not been tested on herring fish fillet until now. The total counts, Enterobacteriaceae, Salmonella sp. and $S$. aureus were analysed to assess the antimicrobial properties of the herbal extracts (Table 3 ). The total counts ranged between $2.48 \pm 0.52$ and $7.20 \pm 0.88$ $\log \mathrm{cfu} / \mathrm{g}$, indicating that the addition of the herbal extract mixture significantly decreased the total counts compared with nisin treatment and the control after 8 weeks of storage. The obtained results are in agreement with other authors; treated smoked silver carp with garlic and ginger extracts ${ }^{44}$. C. botulinum counts were not detected in any samples analysed during the storage time.
Regarding Enterobacteriaceae spp., Salmonella $\mathrm{sp}$. and $S$. aureus counts in the control and nisin treatment samples significantly increased at the end of the experiment. In contrast, the counts of these microorganisms decreased as a consequence of the addition of GGE after 8 weeks of storage. The same trend was found in other studies ${ }^{45,46}$.

\section{Protein oxidation}

Functional properties of protein, such as solubility, gelation and emulsification, differ in food products because of the essence and kind of proteins and their amino acids. Oxidation of amino acids generating carbonyl compounds that can affect the functionality and the quality of meat proteins. So, phenolic compounds as antioxidants able to retard the rate of protein oxidation $47,48,49,50$. The results indicated that after the first week of storage, the total carbonyl formation increased in all treatments and then began to decrease. GGE significantly $(p<0.05)$ decreased the total carbonyl

Table 3. Microbial counts (log cfu/g) on herring fish fillet during refrigerated storage

\begin{tabular}{cccc}
\hline & Control & Nisin & Treatment \\
\hline Total bacterial counts & & & \\
Week 0 & $3.40 \pm 0.36^{\mathrm{a}}$ & $3.23 \pm 0.25^{\mathrm{ab}}$ & $2.48 \pm 0.52^{\mathrm{b}}$ \\
2 & $3.63 \pm 0.51^{\mathrm{a}}$ & $3.58 \pm 0.37^{\mathrm{a}}$ & $3.10 \pm 0.40^{\mathrm{a}}$ \\
4 & $4.86 \pm 0.65^{\mathrm{a}}$ & $4.64 \pm 0.44^{\mathrm{b}}$ & $3.56 \pm 0.51^{\mathrm{b}}$ \\
6 & $6.10 \pm 0.27^{\mathrm{a}}$ & $5.96 \pm 0.68^{\mathrm{a}}$ & $3.86 \pm 0.35^{\mathrm{b}}$ \\
8 & $7.20 \pm 0.88^{\mathrm{a}}$ & $6.56 \pm 0.45^{\mathrm{a}}$ & $4.20 \pm 0.79^{\mathrm{b}}$ \\
Enterobacteriaceae & & & \\
Week 0 & $3.35 \pm 0.3^{\mathrm{a}}$ & $2.86 \pm 0.70^{\mathrm{ab}}$ & $2.16 \pm 0.45^{\mathrm{b}}$ \\
2 & $3.96 \pm 0.77^{\mathrm{a}}$ & $3.43 \pm 0.97^{\mathrm{a}}$ & $2.56 \pm 0.56^{\mathrm{a}}$ \\
4 & $4.96 \pm 0.25^{\mathrm{a}}$ & $3.66 \pm 0.66^{\mathrm{b}}$ & $3.49 \pm 0.34^{\mathrm{b}}$ \\
6 & $5.86 \pm 0.90^{\mathrm{a}}$ & $4.13 \pm 0.35^{\mathrm{b}}$ & $3.73 \pm 0.80^{\mathrm{b}}$ \\
8 & $6.4 \pm 0.52^{\mathrm{a}}$ & $5.10 \pm 0.45^{\mathrm{b}}$ & $3.83 \pm 0.65^{\mathrm{c}}$ \\
Salmonella sp. & & & \\
Week 0 & $1.77 \pm 0.15^{\mathrm{a}}$ & $1.55 \pm 0.13^{\mathrm{a}}$ & $1.46 \pm 0.23^{\mathrm{a}}$ \\
2 & $3.49 \pm 0.25^{\mathrm{a}}$ & $2.04 \pm 0.29^{\mathrm{b}}$ & $1.61 \pm 0.30^{\mathrm{b}}$ \\
4 & $3.63 \pm 0.30^{\mathrm{a}}$ & $2.71 \pm 0.44^{\mathrm{b}}$ & $1.96 \pm 0.35^{\mathrm{c}}$ \\
6 & $4.68 \pm 0.33^{\mathrm{a}}$ & $3.23 \pm 0.25^{\mathrm{b}}$ & $2.23 \pm 0.32^{\mathrm{c}}$ \\
8 & $4.75 \pm 0.41^{\mathrm{a}}$ & $3.83 \pm 0.55^{\mathrm{a}}$ & $2.76 \pm 0.56^{\mathrm{b}}$ \\
Staphylococcus aureus & & & \\
Week 0 & $\mathrm{ND}$ & $\mathrm{ND}$ & $\mathrm{ND}$ \\
2 & $2.63 \pm 0.51$ & $\mathrm{ND}$ & $\mathrm{ND}$ \\
4 & $3.66 \pm 0.64^{\mathrm{a}}$ & $2.33 \pm 0.47^{\mathrm{b}}$ & $1.56 \pm 0.20^{\mathrm{b}}$ \\
6 & $4.16 \pm 0.35^{\mathrm{a}}$ & $2.70 \pm 0.62^{\mathrm{b}}$ & $2.10 \pm 0.52^{\mathrm{b}}$ \\
8 & $4.43 \pm 0.56^{\mathrm{a}}$ & $3.40 \pm 0.36^{\mathrm{b}}$ & $2.33 \pm 0.45^{\mathrm{c}}$ \\
& & & \\
& & & \\
\hline
\end{tabular}

Values are the mean \pm SD $(n=3)$. Different lowercase letters within the same row indicate significant differences $(p<0.05)$. Treatment: ginger and garlic mixture (1:10)

${ }^{*} C$. botulinum ATCC 3584 not detected in samples over the entire storage period 
compound formation. These results (Table 4) illustrate the positive effect of GGE in lowering total carbonyl compound content after treatment with GGE $(2.12 \pm 0.36)$ followed by BHT $(2.69 \pm$ 0.09 ), whereas the highest carbonyl compound content in the control $(3.98 \pm 0.20)$ was observed at 8 weeks. Otherwise, the total carbonyl content in the TBARS herring fillet treatments was constant throughout the storage period, and these findings were in line with those of ${ }^{51}$.

\section{Lipid oxidation}

Lipid oxidation is an important sign of deterioration of food. The measurement of
TBARS is a standard method for monitoring lipid oxidation changes in food during storage. The effects of ginger, garlic and their mixture on the TBARS values of herring fillet are shown in Table 5. At the beginning of the experiment, the TBARS values of all samples were approximately 0.66 $0.89 \mathrm{mg} \mathrm{MDA} / \mathrm{kg}$ herring fillet; then, the values increased rapidly after8 weeks, especially in the control treatment. The TBARS value of the control treatment, $4.10 \pm 0.20 \mathrm{mg} \mathrm{MDA} / \mathrm{kg}$ fillet, was the highest among all the treatments, whereas the samples treated with the mixture of natural extracts was $1.96 \pm 0.20 \mathrm{mg} \mathrm{MDA} / \mathrm{kg}$ fillet. During

Table 4. Values of carbonyl compounds (nmol carbonyl compounds $\mathrm{mg}^{-1}$ of protein) in the muscles of herring fish after treatment with the natural extract, with and without commercial antioxidant, for 8 weeks of storage at $4{ }^{\circ} \mathrm{C}$

\begin{tabular}{|c|c|c|c|c|c|}
\hline \multirow[t]{2}{*}{ Groups } & \multicolumn{5}{|c|}{ Weeks } \\
\hline & 0 & 2 & 4 & 6 & 8 \\
\hline Control & $0.75 \pm 0.06^{a}$ & $1.28 \pm 0.15^{\mathrm{a}}$ & $1.93 \pm 0.30^{\mathrm{a}}$ & $2.94 \pm 0.14^{\mathrm{a}}$ & $3.98 \pm 0.20^{\mathrm{a}}$ \\
\hline BHT & $0.79 \pm 0.03^{a}$ & $1.21 \pm 0.09^{a}$ & $1.59 \pm 0.12^{\mathrm{ab}}$ & $2.52 \pm 0.20^{b}$ & $2.69 \pm 0.09^{b}$ \\
\hline Treatment & $0.82 \pm 0.06^{a}$ & $1.34 \pm 0.15^{a}$ & $1.35 \pm 0.13^{b}$ & $1.91 \pm 0.25^{c}$ & $2.12 \pm 0.36^{c}$ \\
\hline
\end{tabular}

Values are the mean $\pm S D(n=3)$. Different lowercase letters within the same column indicate significant differences $(p<0.05)$. Treatment: ginger and garlic mixture (1:10)

Table 5. TBARS values (mg.MDA. kg-1 sample) in the muscles of herring fish after treatment with natural extract, with and without commercial antioxidant, for 8 weeks of storage at $4{ }^{\circ} \mathrm{C}$

\begin{tabular}{lccccc}
\hline Groups & \multicolumn{5}{c}{ Weeks } \\
& 0 & 2 & 4 & 6 & 8 \\
\hline Control & $0.89 \pm 0.10^{\mathrm{a}}$ & $1.70 \pm 0.18^{\mathrm{a}}$ & $2.45 \pm 0.12^{\mathrm{a}}$ & $3.30 \pm 0.20^{\mathrm{a}}$ & $4.10 \pm 0.20^{\mathrm{a}}$ \\
BHT & $0.68 \pm 0.15^{\mathrm{a}}$ & $1.21 \pm 0.08^{\mathrm{b}}$ & $1.96 \pm 0.12^{\mathrm{b}}$ & $2.58 \pm 0.20^{\mathrm{b}}$ & $3.12 \pm 0.26^{\mathrm{b}}$ \\
Treatment & $0.66 \pm 0.05^{\mathrm{a}}$ & $0.93 \pm 0.10^{\mathrm{c}}$ & $1.13 \pm 0.05^{\mathrm{c}}$ & $1.56 \pm 0.15^{\mathrm{c}}$ & $1.96 \pm 0.20^{\mathrm{c}}$
\end{tabular}

Values are the mean $\pm S D(n=3)$. Different lowercase letters within the same column indicate significant differences $(p<0.05)$. Treatment: ginger and garlic mixture (1:10)

Table 6. Effect of the addition of ginger and garlic extract on the sensory characteristics of herring fish fillet

\begin{tabular}{lcccc}
\hline $\begin{array}{l}\text { Sensory } \\
\text { characteristics }\end{array}$ & Control & Nisin & BHT & Treatment \\
\hline Colour & $7.43 \pm 0.81^{\mathrm{a}}$ & $7.28 \pm 0.77^{\mathrm{a}}$ & $7.15 \pm 0.78^{\mathrm{a}}$ & $7.70 \pm 1.03^{\mathrm{a}}$ \\
Odour & $6.44 \pm 0.53^{\mathrm{a}}$ & $6.63 \pm 1.22^{\mathrm{a}}$ & $6.88 \pm 1.36^{\mathrm{a}}$ & $6.20 \pm 1.18^{\mathrm{a}}$ \\
Taste & $7.92 \pm 1.09^{\mathrm{ab}}$ & $8.20 \pm 0.48^{\mathrm{ab}}$ & $7.40 \pm 1.02^{\mathrm{a}}$ & $8.40 \pm 0.69^{\mathrm{a}}$ \\
Texture & $6.90 \pm 1.14^{\mathrm{a}}$ & $6.80 \pm 0.94^{\mathrm{a}}$ & $7.60 \pm 0.99^{\mathrm{a}}$ & $7.20 \pm 0.85^{\mathrm{a}}$ \\
Appearance & $7.45 \pm 0.43^{\mathrm{a}}$ & $7.50 \pm 0.52^{\mathrm{a}}$ & $6.90 \pm 1.32^{\mathrm{a}}$ & $7.51 \pm 0.62^{\mathrm{a}}$ \\
Overall acceptance & $7.95 \pm 0.59^{\mathrm{ab}}$ & $8.05 \pm 0.76^{\mathrm{ab}}$ & $7.35 \pm 1.05 \mathrm{~b}$ & $8.20 \pm 0.34^{\mathrm{a}}$
\end{tabular}

Values are the mean $\pm S D(n=3)$. Different lowercase letters within the same row indicate significant differences $(p<0.05)$. Treatment: ginger and garlic mixture (1:10) 
storage, the TBARS values of the mixture of natural extracts were always significantly lower than those of the other treatments $(P<0.05)$. These results indicated that GGE decreased the TBARS values in the herring fillet compared to those in the other treatments, which could be related to the effect of the phenolic compounds in the extracts and their function as antioxidant. Several studies have shown that garlic, ginger, cayenne pepper and their mixture possess strong antioxidant activity ${ }^{52}$.

\section{SDS-PAGE}

The major trend observed in Figure (1) is as follows: as the degree of hydrolysis increased, the quantity of high molecular weight proteins decreased, and more proteins bands were present. This trend was also observed in protein hydrolysates made from salmon ${ }^{53}$, sardines ${ }^{54}$ and Atlantic cod viscera ${ }^{55}$. The highest molecular weight peptide presents in all samples in Fig. 1 was $\sim 84 \mathrm{kDa}$. The protein electrophoresis patterns of the herring muscle supernatant at time zero and after storage for 4 weeks and 8 weeks showed a decline in the high molecular weight band (band 3-9), which almost disappeared after 2 months (lanes 3, 6 and 9). The protein pattern of herring fish muscle found in this study is in agreement with previously published results of brines from traditional barrel-salted herring ${ }^{56,57,58}$. The figure shows that the BHT and herbal extract treatments

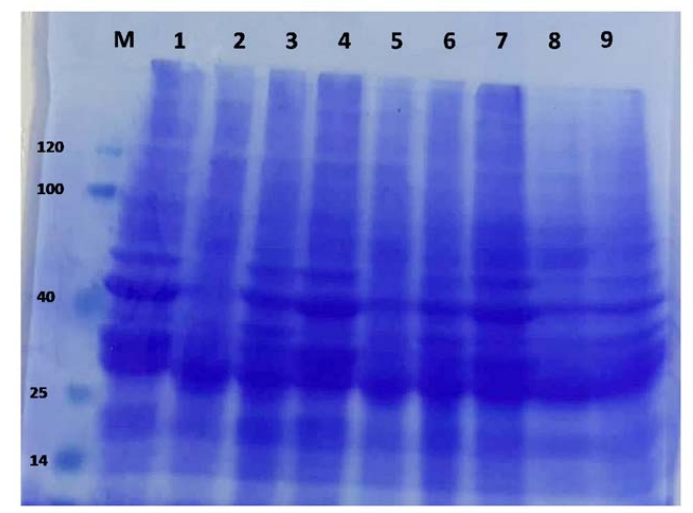

Fig. 1. SDS-PAGE of the supernatants from the muscles of herring fish. Lane M: prestained standard with indicated molecular weight ( $\mathrm{kDa})$; lane 1: control (time zero); lane 2: BHT (time zero); lane 3: herbal extract (time zero); lane 4: control (4 weeks); lane 5: BHT (4 weeks); lane 6: herbal extract (4 weeks); lane 7: control ( 8 weeks); lane 8: BHT ( 8 weeks); and lane 9: herbal extract ( 8 weeks) resulted in intense degradation in the range of 40-26 and 17-10 kDa, and the same trend was observed in previous studies ${ }^{58,57}$, which revealed the existence of bands between 42,50 and $30 \mathrm{kDa}$ as a result of protein degradation in salted herring after a short storage period. Similar results were found in this study. Other studies have reported the degradation of herring myosin reflected in the155, 146, 138, 123, 105, 65 and $56 \mathrm{kDa}$ bands 56 .

\section{Sensory evaluation}

The organoleptic assessment of food products is an essential tool to estimate consumer acceptability ${ }^{59}$. The sensory properties of herring fillet fish, including colour, odour, taste, texture, appearance and acceptance, after treatment of nisin, BHT, and herbal extract compared with those of the control are shown in Table 6. There was a slight significant difference $(P<0.05)$ among all treatments; interestingly, the herbal extract treatments received the highest score in taste and overall acceptance. A similar trend has been reported previously ${ }^{60}$. Thus, these sensory evaluation results indicate that the use of the herbal extract had a positive impact on the sensory quality of the herring fillet.

\section{CONCLUSION}

This study proved that the preservative capacity of GGE was superior to that of BHT and nisin, which are categorized as super-preservative agents. GGE displayed superior antioxidant activity and antimicrobial effects against serious pathogens. Storage experiments with herring fish fillets for 8 weeks at $4{ }^{\circ} \mathrm{C}$ confirmed that GGE addition led to a decrease in TBARS and protein oxidation values, offering good potential to improve the safety, shelf life and sensory qualities of herring fish fillets, which make these extracts appropriate alternative preservatives for use in the food industry.

\section{ACKNOWLEDGEMENTS}

The authors acknowledge the Food Technology Department, Arid Lands Cultivation Research Institute, City of Scientific Research and Technological Applications (SRTA-City), New Borg El-Arab, Alexandria, Egypt for funding the activities presented in this study. 


\section{CONFLICT OF INTEREST}

The authors declares that there is no conflict of interest.

\section{AUTHORS' CONTRIBUTION}

All authors listed have made a substantial, direct and intellectual contribution to the work, and approved it for publication.

\section{FUNDING}

None.

\section{DATA AVAILABILITY}

All datasets generated or analyzed during this study are included in the manuscript.

\section{ETHICS STATEMENT}

This article does not contain any studies with human participants or animals performed by any of the authors.

\section{REFERENCES}

1. Chaillou, S., Chaulot Talmon, A., Caekebeke, H., Cardinal, M., Christieans, S., Denis, C. Origin and ecological selection of core and food-specific bacterial communities associated with meat and seafood spoilage. ISME Journal, 2015; 9: 1105-1118. https:// doi.org/10.1038/ismej.2014.202

2. Hansen, P., Ikkala, P., and Bjornum, M. Holding fresh fish in refrigerated sea water. Bullettin d Institute International de Refrigeration, 1970; 50: 299-309

3. Aubourg, S. P., Rey-Mansilla, M. and Sotelo, C. G. Differential lipid damage in various muscle zones of frozen hake (Merluccius merluccius). Zeitschrift fur Lebensmittel-Untersuchung und -Forschung, 1999; 208:189-193. https://doi.org/10.1007/ s002170050400

4. Xiong YL. 2000. Protein oxidation and implication for muscle food quality. In: E.A. Decker, C. Faustman, C.J. Lopez-Bote (Eds.), Antioxidants in muscle foods: nutritional strategies to improve quality.pp. 85-112. New York: John Wiley and Sons.

5. Bou, R., Guardiola, F., Grau, A., Grimpa, S., Manich, A., Barroeta, A. \& Codony, R. Influence of dietary fat source, ב-tocopherol, and ascorbic acid supplementation on sensory quality of dark chicken meat. Poultry Science, 2001; 80: 800-7. https://doi.org/10.1093/ps/80.6.800

6. Zouari, N., Elgharbi, F., Fakhfakh, N., Bacha, A.B., Gargouri, Y. and Miled, N. Effect of dietary vitamin E supplementation on lipid and colour stability of chicken thighmeat. African Journal of Biotechnology, 2010; 9: 2276-83

7. Artes, F., Gomez, P. and Artes-Hernandez, F. Physical, physiological and microbial deterioration of minimally fresh processed fruits and vegetables. Food Science and Technology International,2007; 13:177-188. https://doi.org/10.1177/1082013207079610
8. Malas, B., Mohamad, M. and Yazji, S.. Nisin production conditions optimization and its effect on Bacillus cereus and Listeria monocytogenes. International Food Research Journal, 2017; 24- 900-903.

9. Gharsallaoui, A., Oulahal, N., Joly, C. and Degraeve, P. Nisin as a Food Preservative: Part 1: Physicochemical Properties, Antimicrobial Activity, and Main Uses. Critical Reviews in Food Science and Nutrition, 2016; 56: 1262-1274. https://doi.org/10.1080/10408398.2 013.763765

10. Haghighi Manesh, S. and Azizi, M. H.. Production and Evaluation of Type of Multi Layer Active Film for Packaging of Pasteurized Milk. Journal of Food Process Engineering, 2017; 40:1-13. https://doi.org/10.1111/ jfpe.12442

11. Shehata, M.G. Badr, A.N. and El Sohaimy, S.A. Novel antifungal bacteriocin from lactobacillus paracasei KC39 with anti-mycotoxigenic properties. Bioscience Research, 2018; 15(4):4171-4183.

12. Shehata, M .G., Abd-Rabou, H.S. and El-Sohaimy, S.A. Plant Extracts in Probiotic Encapsulation: Evaluation of their Effects on Strain Survivability in Juice and Drinkable Yoghurt During Storage and an In vitro Gastrointestinal Model. Journal of Pure and Applied Microbiology,2019a; 13(1). https://doi.org/10.22207/ JPAM.13.1.70

13. Shehata, M.G., Abu-Serie, M.M., Abd El-Aziz, N.M. and El Sohaimy, S.A. In vitro Assessment of Antioxidant, Antimicrobial and Anticancer Properties of Lactic Acid Bacteria. International Journal of Pharmacology, 2019 b; (in press). https://doi. org/10.3923/ijp.2019.651.663.

14. Shehata, M.G., Badr, A. N., El Sohaimy, S.A., Asker, D. Awad, T.S. Characterization of antifungal metabolites produced by novel lactic acid bacterium and their potential application as food biopreservatives. Annals of Agricultural Sciences, 2019 c; (in press). https://doi. org/10.1016/j.aoas.2019.05.002

15. Fernandez-Gines, J.M., Fernandez-Lopez, J., Sayas-Barbera, E. and Perez-Alvarez, J.A. Meat products as functional foods: a review. Journal of Food Science, 2005; 70: 37-43. https://doi. org/10.1111/j.1365-2621.2005.tb07110.x

16. Visciano, P., Perugini, M., Conte, F., Amorena, M. Polycyclic aromatic hydrocarbons in farmed rainbow trout (Oncorhynchus mykiss) processed by traditional flue gas smoking and by liquid smoke flavourings. Food and Chemical Toxicology, 2008; 46:1409-1413. https:// doi.org/10.1016/j.fct.2008.01.001

17. Zouari, N., Elgharbi, F., Fakhfakh, N., Bacha, A.B., Gargouri, Y. \& Miled, N. Effect of dietary vitamin E supplementation on lipid and colour stability of chicken thigh meat. African Journal of Biotechnology, 2010; 9: 2276-83.

18. Uhart, M., Maks, N. \& Ravishankar, S.. Effect of spices on growth and survival of salmonella typhimurium $\mathrm{dt}$ 104 in ground beef stored at 4 and 8c. Journal of Food Safety, 2006; 26:115-125. https://doi.org/10.1111/ j.1745-4565.2006.00036.x

19. Andrzej, S. O., Justyna, Y. B., and Piotr, Z. Carp (Cyprinus carpioL.) lipid oxidation during cold storage. Archives of Polish. Fisheries, 2015; 23:101-106. https://doi. 
org/10.1515/aopf-2015-0011

20. Tenyang, N., Womeni, H. M., Tiencheu, B., Takugan, F. N. H., Tchouanguep, M. F., Villeneuve, P., and Linder, M. Lipid oxidation of catfish (Arius maculatus) after cooking and smoking by different methods applied in cameroon. Food and Nutrition Sciences, 2013; 4:76-187. https://doi.org/10.4236/fns.2013.49A1025

21. Cao, Y., Gu, W., Zhang, J., Chu, Y., Ye, X., Hu, Y. and Chen, J. Effects of chitosan, aqueous extract of ginger, onion and garlic on quality and shelf life of stewedpork during refrigerated storage. Food chemistry, 2013; 141(3):1655-1660. https://doi.org/10.1016/j. foodchem.2013.04.084

22. Singleton, V.L., Orthofer, R. and Lamuela-Ravent $\rceil s$, R.M. Analysis of total phenols and other oxidation substrates and antioxidants by means of folin-ciocalteu reagent. Methods in enzymology, 1999; 299:152-178. https://doi.org/10.1016/S0076-6879(99)99017-1

23. Kim, D. O., Chun, O. K., Kim, Y. J., Moon, H. Y., \& Lee, C. $Y$. Quantification of polyphenolics and their antioxidant capacity in fresh plums. Journal of Agricultural and Food Chemistry, 2003; 51:6509-6515. https://doi. org/10.1021/jf0343074

24. Shirwaikar, A., Shirwaikar, A., Rajendran, K. \& Punitha, I.S. In vitro antioxidant studies on the benzyl tetra isoquinoline alkaloid berberine. Biological and Pharmaceutical Bulletin, 2006; 29:1906-10. https:// doi.org/10.1248/bpb.29.1906

25. Kato, K., Terao, S., Shimamoto, N. and Hirata M. Studies on scavengers of active oxygen species. 1. Synthesis and biological activity of 2-O-alkylascorbic acids. Journal of Medicinal Chemistry, 1988; 31:793-8. https://doi.org/10.1021/jm00399a019

26. Panda, S. K., Thatoi, H. N. and Dutta, S. K.. Antibacterial activity and phytochemical screening of leaves and bark extracts of Vitex negundo L. Journal of Medicinal Plants Research, 2009; 3: 294-300.

27. Liu, F., Dai, R., Zhu, J. \& Li, X. Xingmin. Optimizing color and lipid stability of beef patties with a mixture design incorporating with tea catechins, carnosine, and ב-tocopherol. Journal of Food Engineering,2010; 98:170-177. https://doi.org/10.1016/j. jfoodeng.2009.12.023

28. Oliver, C. N., Ahn, B.W., Moerman, E. J., Goldstein, S., \& Stadtman, E. R. (1987). Aged-related changes in oxidised proteins. Journal of Biological Chemistry, 262: 5488-5491.

29. Eaton, A. D., Clesceri, L. S. \& Greenberg A. E., (1998). Standard Methods for the Examination of Water and Wastewater, (20th ed.). American Public Health Association, Washington, D.C.

30. Wehr, H. M. \& Frank J. H. (2004). Standard Methods for the Microbiological Examination of Dairy Products, (17th ed.), APHA Inc., Washington, D.C

31. Knowles, J.R., Roller, S., Murray, D.B. \& Naidu, A.S. Antimicrobial action of carvacrol at different stages of dual-species biofilm development by Staphylococcus aureus and Salmonella enterica Serovar Typhimurium. Applied and Environmental Microbiology, 2005; 71: 797 - 803. https://doi.org/10.1128/AEM.71.2.797803.2005

32. Lawless, H. T., and Heymann, H. 1998. In sensory evaluation of food. New York: Chapman \& Hall. https:// doi.org/10.1007/978-1-4615-7843-7

33. Ghasemi, K., Ghasemi, Y. and Ebrahimzadeh, M.A. Antioxidant activity, phenol and flavonoid contents of 13 citrus species peels and tissues. Pakistan journal of pharmaceutical sciences, 2009; 22:277-281.

34. Benkeblia, N. Free-radical scavenging capacity and antioxidant properties of some selected onions (Allium cepa L.) and garlic (Allium sativum L.) extracts. Brazilian Archives of Biology and Technology, 2005; 48: 753-759. https://doi.org/10.1590/S1516-89132005000600011

35. Nuutila, A. M., Puupponen-Pimia, R., Aarni, M. and Oksman-Caldentey. Comparison of antioxidant activities of onion and garlic extracts by inhabitation of lipid peroxidation and radical scavenging activities. Food Chemistry, 2003; 81: 485-493. https://doi. org/10.1016/S0308-8146(02)00476-4

36. Cappaso, A. The antioxidant action and therapeutic efficacy of Allium sativum L. Molecules, 2013; 18:690700. https://doi.org/10.3390/molecules 18010690

37. Ghasemzadeh, A., Jaafar, H.Z.E. and Rahmat, A. Antioxidant activities, total phenolics and flavonoids content in two varieties of Malaysian young ginger (Zingiber officinalis Roscoe). Molecules, 2010; 15:43244333. https://doi.org/10.3390/molecules15064324

38. Wojtaszek, K. Oxidative burst: an early plant response to pathogen infection. Biochemical Journal, 1997; 322: 681-692. https://doi.org/10.1042/bj3220681

39. Lin, Y.T., Labbe, R.G. and Shetty, K. Inhibition of Listeria monocytogenes in fish and meat systems by use of oregano and cranberry phytochemical synergies. Applied and Environmental Microbiology, 2004; 70: 5672-5678. https://doi.org/10.1128/AEM.70.9.56725678.2004

40. Nowak, A., Czyzowska, A., Efenberger, M. \& Krala, L. Polyphenolic extracts of cherry (Prunus cerasus L.) and blackcurrant (Ribes nigrum L.) leaves as natural preservatives in meat products. Food Microbiology, 2016; 59: 142-9. https://doi.org/10.1016/j. fm.2016.06.004

41. Shehata, M.G. Badr; A.N. Abdel-Razek, A.G.; Hassanein, M. M. and Amra, H. A. Oil bioactive Films as an Antifungal Application to Save Post-Harvest Food Crops, Annual Research and Review in Biology,2017; 16: 1-16. https://doi.org/10.9734/ARRB/2017/36149

42. Abdulzahra, M. D. and Mohammed, H. F.. The Antibacterial Effect of Ginger and Garlic Extracts on Some Pathogenic Bacteria Isolated from Patients with Otitis Media. International Research Journal of Medical Sciences, 2014; 2: 1-5.

43. Fredotovir, . and Puizina, J. Edible allium species: chemical composition, biological activity and health effects. Italian Journal of Food Science, 2018; 31:1.

44. Frank, F., Xu, Y., jiang, Q. and Wenshui Xia, W.. Protective effects of garlic (Allium sativum) and ginger (Zingiber officinale) on physicochemical and microbial attributes of liquid smoked silver carp (Hypophthalmichthys molitrix) wrapped in aluminium foil during chilled storage. African Journal of Food Science, 2014; 8: 1-8. https://doi.org/10.5897/AJFS2013.1030

45. Islam, K., Rowsni,A. A., Khan, M. M. and Kabir, M.. Antimicrobial activity of ginger (Zingiber Officinale) 
extracts against Food-Borne pathogenic bacteria. International Journal of Science, Environment and Technology, 2014; 3: 867-871.

46. Zhang, H., Wu, J., and Guo, X. Effects of antimicrobial and antioxidant activities of spice extracts on raw chicken meat quality. Food Science and Human Wellness, 2016; 5:39-48. https://doi.org/10.1016/j. fshw.2015.11.003

47. Tajkarimi, M. M., Ibrahim, S. A., and Cliver, D. O. Antimicrobial herb and spice compounds in food. Food Control, 2010; 21: 1199-1218. https://doi. org/10.1016/j.foodcont.2010.02.003

48. Serpen, A., Gokmen, V. and Fogliao, V. Total antioxidant capacities of raw and cooked meats. Meat science, 2012; 90:60-65. https://doi.org/10.1016/j. meatsci.2011.05.027

49. Jiang, J., \& Xiong, Y. L. L. Natural antioxidants as food and feed additives to promote health benefits and quality of meat products: A review. Meat Science, 2016; 120: 107-117. https://doi.org/10.1016/j. meatsci.2016.04.005

50. Zhang, H., Wu, J., and Guo, X. Effects of antimicrobial and antioxidant activities of spice extracts on raw chicken meat quality. Food Science and Human Wellness, 2016; 5: 39-48. https://doi.org/10.1016/j. fshw.2015.11.003

51. Fasseas, M.K., Mountzouris, K.C., Tarantilis, P.A., Polissiou, M. and Zervas, G. Antioxidant activity in meat treated with oregano and sage essential oils. Food Chemistry, 2007; 106: 1188-94. https://doi. org/10.1016/j.foodchem.2007.07.060

52. Otunola, G.A. and Afolayan, A. J. Evaluation of the polyphenolic contents and some antioxidant properties of aqueous extracts of Garlic, Ginger, Cayenne Pepper and their mixture. Journal of Applied Botany and Food Quality, 2013; 86: 66 - 70.

53. Kristinsson, H. G. \& Rasco, B. A. Fish protein hydrolysates: production, biochemical, and functional properties. Critical Reviews in Food Science and Nutrition, 2000; 40: 43-81. https://doi. org/10.1080/10408690091189266

54. Quaglia, G. B. and Orban, E. Influence of enzymatic hydrolysis on structure and emulsifying properties of sardine (Sardina pilchardus) protein hydrolysates. Journal of Food Science, 1990; 55: 1517-1573. https:// doi.org/10.1111/j.1365-2621.1990.tb03571.x

55. Aspmo, S. I., Horn, S. J. and Eijsink, V. G. H. Enzymatic hydrolysis of Atlantic cod (Gadus morhua L.) viscera. Process Biochemistry, 2005; 40: 1957-1966 https:// doi.org/10.1016/j.procbio.2004.07.011

56. Rodger, G., Hastings, R., Cryne, C. and Bailey, J. Diffusion properties of salt and acetic acid into herring and their subsequent effect on the muscle tissue. Journal of Food Science, 1984; 49: 714-720. https:// doi.org/10.1111/j.1365-2621.1984.tb13194.x

57. Andersen, E., Andersen, M.L. \& Baron, C.P. Characterisation of oxidative changes in salted herring (Clupeaherengus) during ripening. Journal of Agricultural and Food Chemistry, 2007; 55:9545-9553. https://doi.org/10.1021/jf071369b

58. Christensen, M., Andersen, E., Christensen, L., Andersen, M.L. and Baron, C.P. Textural and biochemical changes during ripening of old-fashioned salted herrings. Journal of the Science of Food and Agriculture, 2011; 91: 330-336. https://doi. org/10.1002/jsfa.4190

59. Mohamed, G.F., Hegazy, E.M. and Abdellatef, M. Physicochemical properties and mycotoxins contents of Tilapia fish-fillets after solar drying and storage. Global Veterinaria, 2011; 7: 138-148

60. Iheagwara, M.C. Effect of Ginger Extract on Stability and Sensorial Quality of Smoked Mackerel (Scomber scombrus) Fish. Nutrition \& Food Science, 2013; 3: 3. https://doi.org/10.4172/2155-9600.1000199 